\title{
RISKS OF REGIONAL TAX SYSTEMS AND THEIR PORTFOLIO DECOMPOSITION: THE CASE OF MODERN RUSSIA
}

\author{
Marina Malkina ${ }^{1}$, Rodion Balakin ${ }^{1}$ \\ ${ }^{1}$ Center of Macro and Microeconomics, Institute of Economics and Entrepreneurship, Lobachevsky State \\ University of Nizhni Novgorod, 23 Prospekt Gagarina, 603950 Nizhni Novgorod, Russia
}

Link to this article: https://doi.org/10.11118/actaun202068060995

Received: 15. 3. 2020, Accepted: 29. 10. 2020

To cite this article: MALKINA MARINA, BALAKIN RODION. 2020. Risks of Regional Tax Systems and Their Portfolio Decomposition: The Case of Modern Russia. Acta Universitatis Agriculturae et Silviculturae Mendelianae Brunensis, 68(6): 995-1009.

\begin{abstract}
The purpose of this paper is an assessment of the risk of regional tax systems at different levels of the budget system (consolidated, federal, regional and local), decomposition of this risk by sources (various taxes and tax groups) and the isolation of internal (related to own tax return volatility) and external (related to the correlation of tax returns volatility) risk components. Using the portfolio approach, we measured and decomposed the risk of tax systems of 80 constituent entities of the Russian Federation in 2006-2017. As a result, we found a weak positive relationship between the risk and return of the regional tax systems at all budget levels. By comparing the structure of return and risk of regional tax systems, we identified taxes - risk dampers and taxes - risk enhancers, and estimated the overall level of imbalance in regional tax systems at the studied budget levels. It allowed us to conclude about the effectiveness of diversification of regional tax systems, the advisability of combining different taxes in a single portfolio, or transferring them to another level of the budget system.
\end{abstract}

Keywords: Russian tax system, tax return, tax risk, portfolio approach, decomposition, levels of budget system, diversification, imbalance

\section{INTRODUCTION}

The tax systems of countries and regions have a number of significant characteristics, among which the most important are tax return, tax buoyancy, elasticity of tax revenue with respect to tax rate or tax base. In this study, we are interested in another characteristic - the risk of the tax system and its structure, as well as its relationship with the return of the tax system and its structure. By the return of the tax system we understand the ratio of tax revenues to the gross domestic product (GDP) of a country or the gross regional product (GRP) of a region. By the risk of the tax system we mean the variance or standard deviation or coefficient of variation of the tax return. The transition from absolute (revenue) to relative (return) indicators of the tax system allows us to strengthen the stationarity of time series.

To decompose the risk of tax systems by sources, the portfolio approach of Markowitz (1952) and Sharpe (1970) in combination with the statistical method of variance decomposition of Shorrocks (1982) is quite applicable. In this case, we can consider the tax system of a certain region or country as a tax portfolio consisting of separate taxes, which are sources of both return and risk. The risk of a portfolio depends on its structure the share of each tax or tax group), the risk of each tax and the inter-temporal covariances of the return of various taxes. 
Our study concerns Russia, which is classified as a federal state. The total amount of taxes collected in its different territories forms the so-called consolidated budget. These taxes are distributed between the federal budget (go to the federal level) and the budgets of the constituent entities of the Russian Federation (regional level) in accordance with federal law, primarily the Budget Code of RF. Further, the tax revenues of regional budgets are partially shared with local budgets. Additionally, two local taxes in Russia (Personal Property Tax and Land Tax) are directly assigned to the local level. The distribution of others, such as Personal Income Tax, between the region and municipalities is carried out in accordance with the applicable laws of the constituent entities of the Russian Federation. Thus, the local level of the budget system is formed. Eventually, we have a distribution of tax revenues and tax risks between the three levels of the budget system (federal, regional and local).

The use of the portfolio approach to the assessment of the structure of the tax system risk and return both at the consolidated level and at three particular levels of the budget system allows to answer the question of which taxes are dampers and which are amplifiers of the tax system risk at each level. The application of this approach also gives us an opportunity to determine how effective the structure of the tax system is at each level. The subsequent division of the risk of each tax into internal (associated with its own volatility) and external (associated with the correlation of this tax return with the return of other taxes) enables us to find out how well the tax portfolio of each level of the budget system is diversified. Finally, a comparison of the risk structure of the country and mid-regional portfolios can indicate the effectiveness of transferring a certain tax to the federal level or, conversely, keeping it in the structure of territorial budgets.

\section{Literature Overview}

First of all, some economists drew attention to the possibility of application of the portfolio approach, originally proposed by Markowitz (1952) and Sharpe (1970) for investment portfolio management, in other areas. In particular, Garret (2009) and Seegert (2012, 2017) were among the first to adapt it for the assessment of the tax system risks. Albrecht (2013) also substantiated the appropriateness of using the portfolio approach to assess the volatility of tax revenues.

Using this approach, Seegert (2012) evaluated the degree of balance in the tax portfolios of the US states and identified excess or insufficient tax burden on individual taxes. According to this scientist, an unbalanced tax portfolio is characterized by high volatility of tax revenues, which increases uncertainty, negatively affects the expectations of business entities, and inhibits economic growth.
Garret (2009) solved the problem of optimizing the structure of the tax portfolio in the economic cycle. He used the objective function to minimize the variance of total tax revenues and constructed regression dependence of tax revenues on income tax and other taxes.

Some researchers investigated the dependency between the volatility of tax revenues and key macroeconomic indicators, especially the rate of economic growth. For example, the study on the relationship between economic growth and tax structure by Liapis et al. (2014) revealed different tax regimes in the EU countries. The research by Fricke and Sussmuth (2014), based on data from Latin American countries, explored the relationship between the structure of taxation and economic growth in unstable economies using indicators of the elasticity of tax revenues to economic growth rates in the short and long term. This study identified the taxes with a faster or slower reaction to production dynamics, as well as with an asymmetric response to it. The authors proposed specific measures of tax policy aimed at maximizing tax revenues while maintaining positive production dynamics, taking into account the reaction of tax revenues to economic growth.

To identify the effective structure of tax systems in different countries, Seyfried and Pantuosco (2003) applied the objective function of minimizing the standard deviation of tax revenue growth rates. The authors concluded that the effectiveness of the tax system, as a rule, increases with a decrease in the share of corporate income tax or its analogues.

A number of scholars used the value at risk indicator (VaR) to assess the efficiency of tax systems. For example, Cornia and Nelson (2010) employed it to analyze the efficiency of tax policy in some US states. Other researchers (Salin et al., 2004), based on VaR, calculated the size of the insurance fund for the case of crisis and tax cuts. In the study by Felix (2008), the VaR indicator was supplemented by calculating the elasticity of economic growth with respect to the volatility of collected tax revenue. Some authors also analyzed the impact of tax system tools on its effectiveness. For example, Cornia et al. (2016), based on tax returns from the State of Utah (USA) for 21 years and using simulation modeling methods, proved the positive impact of replacing tax benefits with a tax credit system on the effectiveness of the tax system.

Some works were devoted to the structural decomposition of the profitability and volatility of the tax system. For example, Dauchy and Balding (2013) decomposed personal income tax by source (salary, capital income, and business income) to determine which one contributed more to the volatility of the tax system. The authors found that since 1986 in the United States the growth of tax revenues from capital income was predominant, and payroll taxes showed the least volatility. They 
concluded that the increase in the volatility of US tax revenues was driven by a shift in the tax burden in favor of high-income individuals, an increase in the share of capital income in tax revenues, and an increase in the volatility of capital income.

Some scholars explored the relationship between economic diversification and instability of tax revenue. For example, Carrol (2009) investigated the impact of the level of economic diversification and the complexity of tax systems on their stability. She showed that economic diversification reduces the volatility of tax revenues, while the tax system complexity increases it. Research by Malkina (2017), based on the construction of an econometric model with a number of control variables, proved a positive relationship between the level of economic specialization and the tax return instability in the Russian regions.

The studies devoted to assessing the risk of the Russian tax system and the factors affecting it are of particular interest in the context of this research. For example, Mishustin (2016) revealed a different influence of groups of factors (socio-economic, legislative, and factors of tax administration) on the revenues of the budget system of the Russian Federation from the most productive taxes (Corporate Income Tax - CIT, Personal Income Tax - PIT, Value Added Tax - VAT, Mineral Extraction Tax - MET, Excise Taxes - ET). Malkina and Balakin (2015, 2017) were the first to apply the portfolio approach for assessment of the risk of tax systems of the Russian Federation and its regions, as well as for its decomposition by industry and region. In our new study, we consider certain taxes and tax groups as sources of tax system return and risk, and use more recent data for 2006-2017 on Russian regions. In addition, we carry out a deeper decomposition of the tax system risk, separating its internal and external components for each tax.

It should be emphasized that the rules adopted in the Russian tax system are specifically aimed at achievement of the goals of intergovernmental fiscal policy. The distribution of taxes between the levels of the budget system is subordinated to the task of equalizing the level of budgetary provision of the regions. Indeed, in accordance with the established procedure, taxes that are most unevenly distributed among regions (MET and VAT) are fully or almost completely transferred to the federal budget of the Russian Federation. At the same time, another highly productive tax, Personal Income Tax, which is characterized by the smallest interregional differences in per capita income, remains completely in the territorial budgets. Therefore, the existing system of tax distribution between the federal center and the constituent entities significantly contributes to the equalization of Russian regions in terms of budgetary provision. Moreover, its impact on horizontal budget equalization is even higher than the impact of the intergovernmental transfer system (Malkina, 2016). This allows us to positively assess the Russian tax distribution system in terms of reducing interregional differences in budgetary provision. However, the impact of the tax distribution system on the risk-sharing in the budgetary system also does matter. Assessment and decomposition of the tax system risk at different levels of the budget system should shed light on this issue.

Thus, in this study we set a number of goals: a) using the portfolio approach, to measure the Russian regions' tax systems risks for consolidated, federal, regional and local budgets and to decompose them by source; b) to identify taxes that play the role of dampers and amplifiers of the volatility of tax revenues at each level of the budget system; c) to characterize the effectiveness of diversification of the tax portfolio at each level of the budget system.

\section{MATERIALS AND METHODS}

We used the annual data of the Federal Tax Service of the Russian Federation (FTS RF) for 20062017. It covers tax revenues and their distribution between the levels of the budgetary system of 80 constituent entities of the Russian Federation, hereinafter referred to as regions. For these regions, we also used annual gross regional product (GRP) data provided by the Federal State Statistics Service of the Russian Federation (FSSS RF). In our study, Tyumen and Arkhangelsk oblasts were considered together with their autonomous regions.

In analysis of the Russian tax system, we apply the following grouping, consisting of 5 taxes and 3 combined tax groups:

1. Corporate Income Tax, CIT (more precisely called Profit tax);

2. Personal Income Tax, PIT;

3. Value Added Tax, VAT;

4. Excise Taxes;

5. Duties;

6. Natural Resources Taxes (including Mineral Extraction Tax, MET, which provides about 98-99\% of the tax revenue of this group; as well as regular payments for mineral extraction (royalties) when fulfilling production sharing agreements; water resources tax; fees for exploiting of wildlife and for the use of aquatic biological resources);

7. Property Taxes (including Corporate Property Tax, Personal Property Tax, Transport Tax, Land Tax, Qambling Tax, and Real Estate Tax specifically established for the cities of Veliky Novgorod and Tver);

8. Special Tax Modes (United Agricultural Tax, Simplified Tax System, Presumptive Tax System, and since 2013 Patent Based Simplified Tax System), involving a number of benefits for agricultural enterprises, field developers and small and medium-sized businesses. 
It should be emphasized that in the period under review there were no significant institutional changes that could substantially affect the return and risk of regional tax systems. However, some changes have indeed occurred. First of all, since 2009, the CIT has been reduced from $24 \%$ to $20 \%$, but the distribution of this tax between the federal and regional budgets has also been changed. Until 2009, 6.5\% of this tax was directed to the federal budget, and $17.5 \%$ went to the budgets of the constituent entities of the Russian Federation (regional budgets). Since 2009, this ratio has changed by $2 \%$ allocated in the federal budget against $18 \%$ in the regional budgets. In addition, in 2009 the MET calculation formula was altered, the state specified a number of benefits and exemptions for this tax, taking into account the quality of mineral deposits and the stage of their development. Meanwhile, our previous study (Malkina and Balakin, 2015) showed that these institutional changes did not significantly affect the risks of tax systems in the regions, mainly because they were largely driven by the logic of their previous development.

Next, we present the methodology for calculating the tax systems return and risk and their decomposition, as well as the level of imbalance in the tax system.

The tax return of each $i$-th region was calculated as the ratio of tax revenue $\left(T_{i}\right)$ to gross regional product - GRP $\left(Y_{i}\right)$, and then it was decomposed into K taxes:

$t_{i}=T_{i} / Y_{i}=\sum_{k=1}^{K} t_{i k}$,

where: $k=1, K$ - serial number of the tax or tax group; $t_{i k}=T_{i k} / Y_{i k}-$ tax return of each $k$-th tax in $i$-th region, $T_{i k}-$ tax revenue, and $Y_{i k}$ - gross regional product (GRP) of this region.

The risk of the tax system in each $i$-th region was calculated on the basis of the intertemporal variance of tax return in this region:

$\sigma_{i}^{2}=\frac{1}{N} \sum_{j=1}^{N}\left(t_{i j}-t_{i}\right)^{2}$

where $j=1, N$ - serial number of the year, and $N$ - the number of years under consideration.

Further, using the Shorrocks (1982) technique, we carried out an additive decomposition of the total risk of the regional tax system by taxes and their groups:

$\sigma_{i}^{2}=\sum_{k=1}^{k} \theta_{i k}=\sum_{k=1}^{K} \operatorname{Cov}_{j}\left(t_{i j k} ; t_{i j}\right)$,

In addition, we decomposed the risk created by each tax into internal or within risk $\left(\theta_{w}\right)$, related to its own variance of tax return, and external or between risk $\left(\theta_{B}\right)$, associated with the covariances of this tax return with other tax returns:

$\theta_{i k}=\underbrace{\operatorname{Var}\left(t_{i k}\right)}_{\theta_{W}}+\underbrace{\sum_{l=1, l \neq k}^{L} \operatorname{Cov}_{j}\left(t_{i k} ; t_{i l}\right)}_{\theta_{B}}$,

The comparison of each tax contribution to return $\left(\alpha_{i k}\right)$ with its contribution to risk of tax system $\left(\beta_{i k}\right)$ allows to identify taxes and tax groups playing the role of dampers and amplifiers of instability of the regional and country tax systems at correspondent level of budget system.

The overall level of imbalance in the tax system can be assessed using the structural similarity index $(S S I)$ :

$S S I_{i}=\sqrt{\sum_{k=1}^{K}\left(\alpha_{i k}-\beta_{i k}\right)^{2}}$

For assessment and decomposition of the risk of the country tax system as a whole, we can apply the same methodology as for the region. However, in this case, this approach will even out or reinforce inter-regional differences, depending on the sign of covariance of the regional tax returns. Therefore, to assess the contribution of each tax to the risk of the mid-regional tax portfolio $\left(\bar{\theta}_{k}\right)$, we use the following formula:

$\bar{\theta}_{k}=\sum_{i}^{m} \theta_{i k} \times S_{i}$,

where

$S_{i}=Y_{i} / \sum_{i=1}^{m} Y_{i}$

the share of $i$-th region in total GRP of all regions. Comparison of the contribution of each tax or tax group to the return of the country tax system with its contribution to the mid-regional risk indicates the direction of its effective assignment.

Finally, the application of the above methodology allows us to evaluate the effectiveness of the existing diversification of the tax system of the Russian Federation at different levels of the budget system.

\section{RESULTS}

First of all, we assessed the risks of regional tax systems at four levels of the budget system: consolidated (level of the consolidated budget of the country), federal, regional (level of the consolidated budget of the subject of the Russian Federation) and local. The absolute risk of the country tax system, as measured by the standard deviation of the tax return, amounted to $1.54 \%$ at the consolidated level, 
$1.25 \%$ at the federal level, $0.73 \%$ at the regional level, and $0.26 \%$ at the local level. Thus, the highest absolute risk was observed at the federal and consolidated levels.

However, the absolute tax risk depends on the average tax return. To eliminate this effect, we calculated the relative risk using the coefficient of variation, which is the ratio of the absolute risk to the mean value of tax return. For the country as a whole, this coefficient was 0.071 at the consolidated level, 0.123 at the federal level, 0.064 at the regional level, and 0.150 at the local level. Based on this, we can conclude that the greatest relative risk is typical for local budgets, followed by the federal budget. The first is due to the instability of local budget revenues, which are formed mainly from low-income and difficult to collect taxes. The second is explained by the fact that the federal budget appropriates the most productive, but at the same time highly dependent on macroeconomic conditions taxes, primarily MET and VAT. The smallest value of relative risk is identified at the regional level. This is due to the fact that the main source of tax revenues of regional budgets is Personal Income Tax, which return is relatively stable over time.

For all levels of the budget system, we found a weak and unstable relationship between return and risk of regional tax systems, which is presented in Fig. 1. This is mainly due to the heterogeneity of regional tax systems, which differ in the sectoral structure of the economy and, accordingly, in the structure of tax revenues.

Then we analyzed the interregional differences in the absolute and relative risk of regional tax systems for all levels of the budget system.

At the consolidated level, the tax systems' absolute risk varies from $0.5 \%$ and $0.6 \%$ in Rostov and Moscow oblasts to $8.17 \%$ and $8.67 \%$ in Sakhalin Oblast and Zabaykalsky Krai, respectively. The relative risk, determined on the basis of the coefficient of variation, shows the maximum levels in Zabaykalsky Krai (0.624) and Chechen Republic (0.576), and the minimum levels in Moscow and Rostov oblasts (0.029 and 0,033). Fig. 2 shows the differences between Russian regions in the relative risk of tax systems for consolidated budgets.

At the federal budget level, the risk of regional tax systems is also very scattered. Its maximum absolute values are observed in the lagging Chechen Republic (5.3\%) and Republic of Kalmykia (5.14\%). The most stable tax revenues to the federal budget come from Republic of Ingushetia (0.35\%), as well as Vladimir and Kirov oblasts (0.37\%). Taking into account dependency of absolute risk on absolute return, we again calculated the relative risk based on the coefficient of variation. According to this indicator, the highest risk is observed in Chukotka Autonomous Okrug (12.9), followed by the Altai Krai (6.3). The lowest relative risk for the federal budget revenues is characteristic of the tax systems of Vladimir
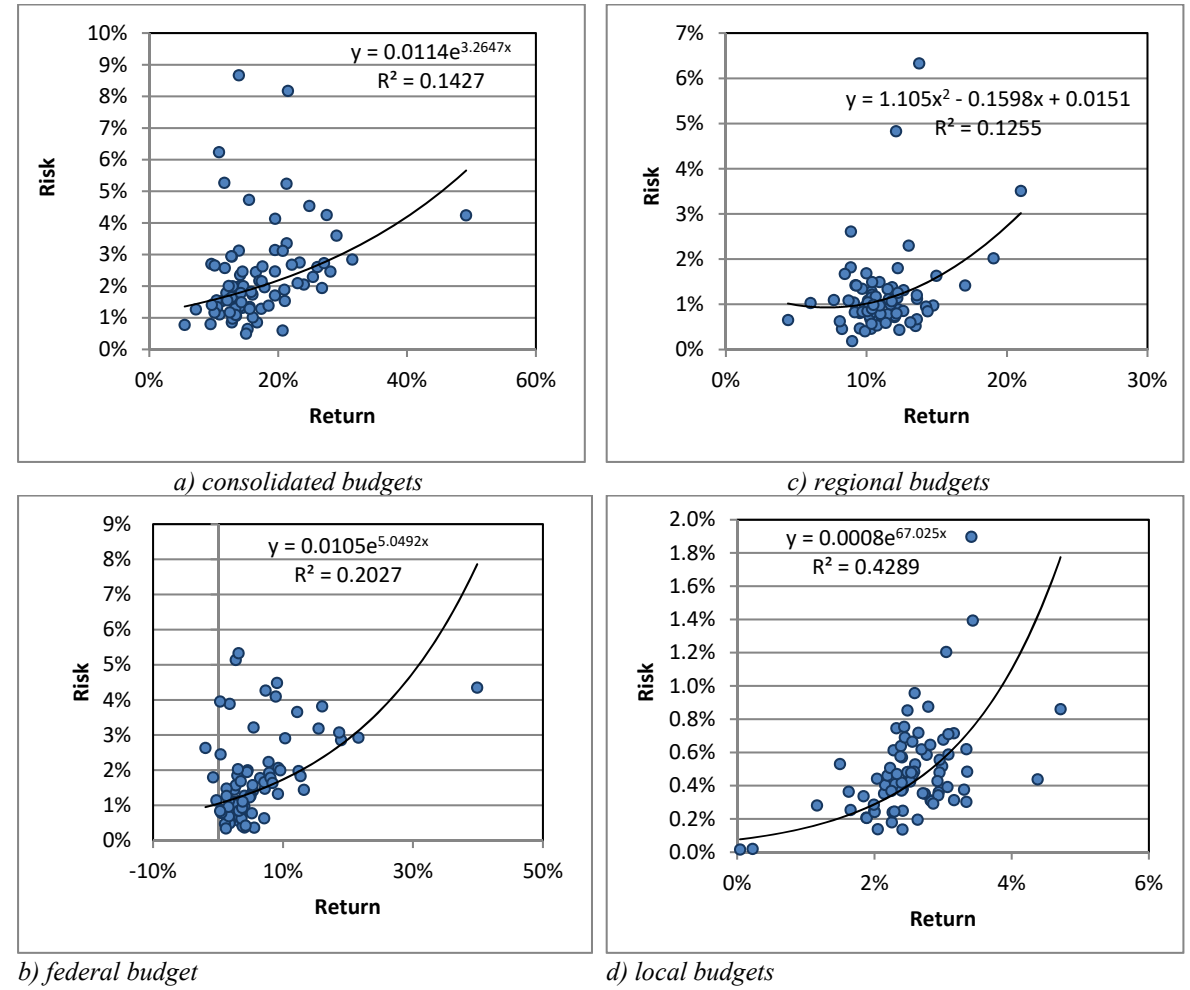

b) federal budget

d) local budgets

1: Correlation between return and risk of regional tax systems for budgets of different levels, 2006-2017

Source: The author's own calculations based on data provided by FTS and FSSS of RF 


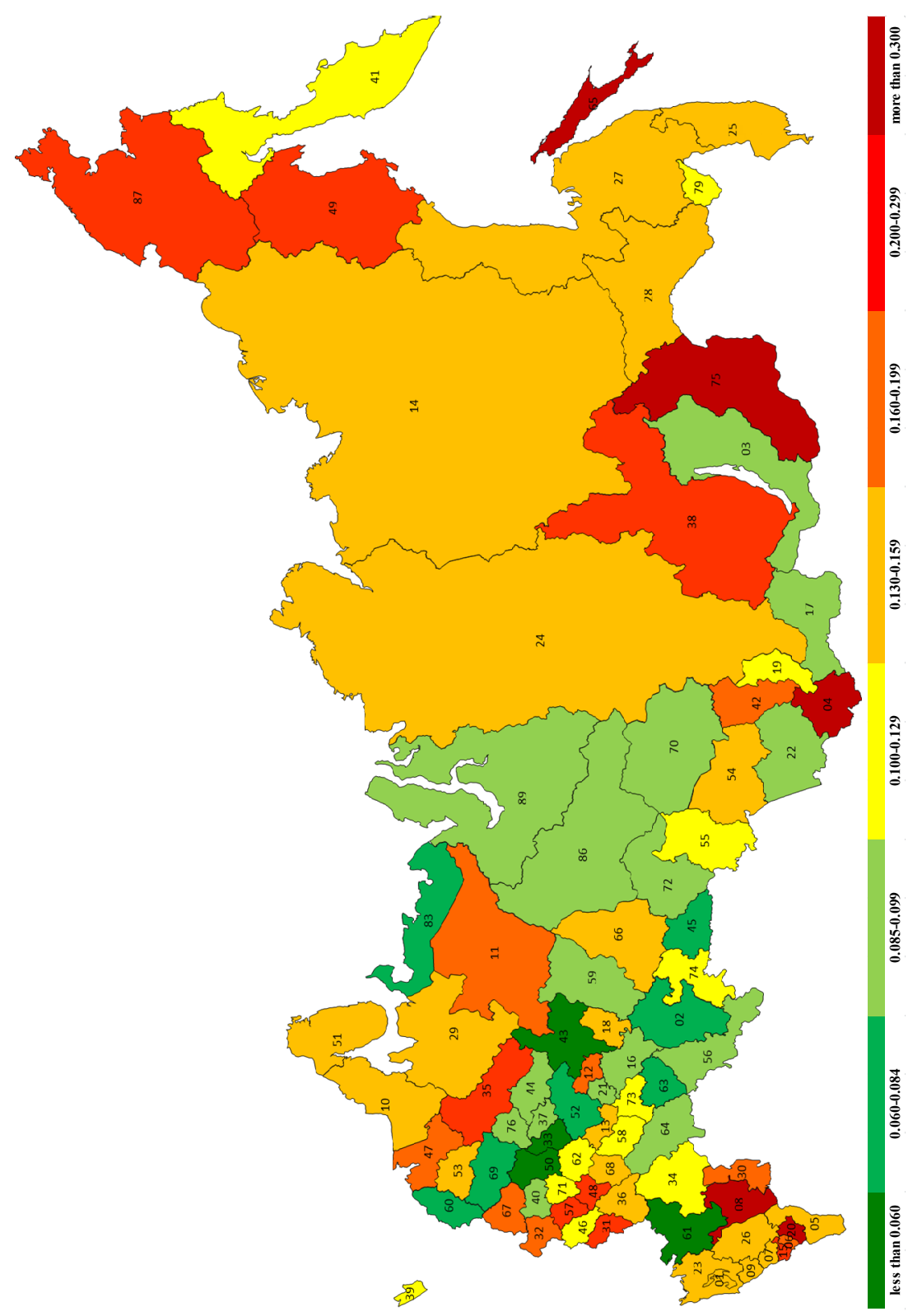

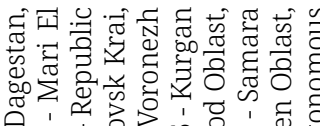

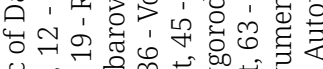

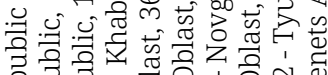

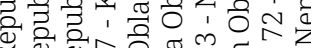

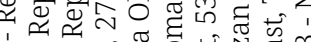

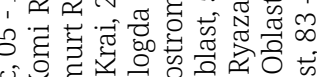

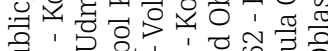

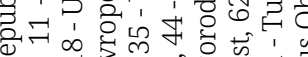

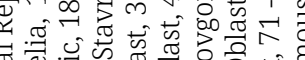

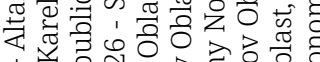

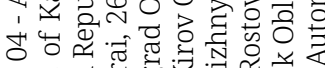

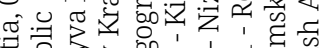

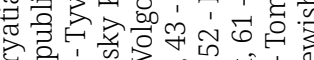

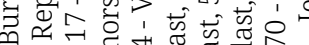

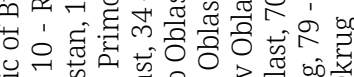

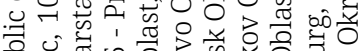

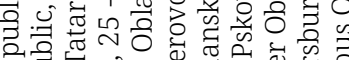

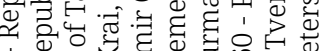
1.

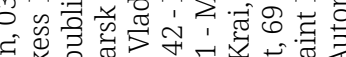

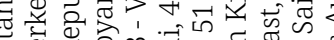

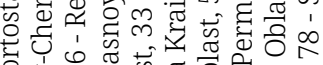

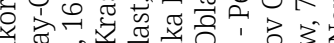

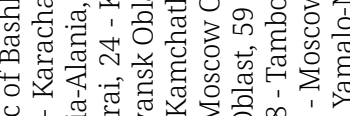

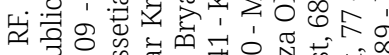

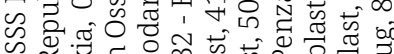

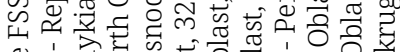

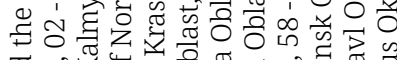
ర్

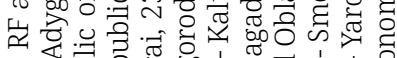

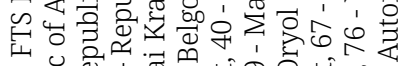

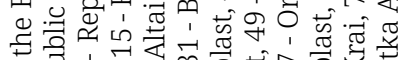

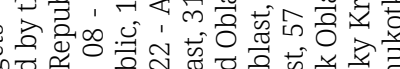

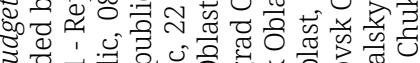

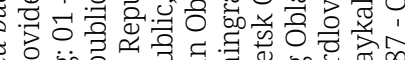
造.

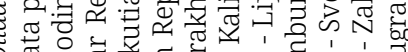

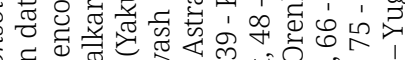

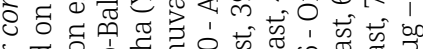
ᄒᄒ

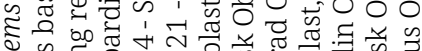

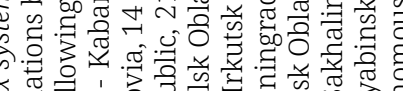

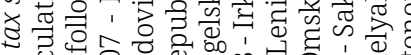

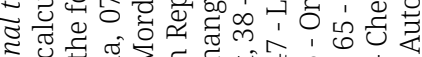

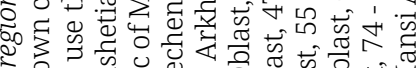
—

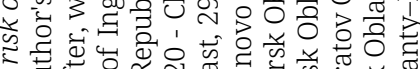

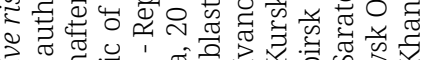

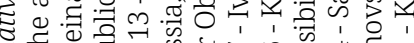

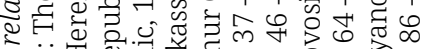

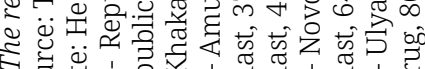

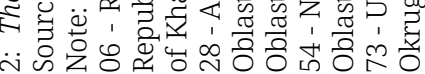


and Moscow oblasts (0.07 and 0.09, respectively). Moreover, the spread of relative risk (determined by its standard deviation) at the federal level is 17 times greater than at the consolidated level. Interregional differences in the relative risk of regional tax systems for the federal budget are presented on the map of the Russian Federation in Fig. 3.

At the level of regional budgets, the maximum absolute risk is found in some Far Eastern and Siberian regions: Sakhalin Oblast (6.33\%), Zabaykalsky Krai (4.83\%) and Chukotka Autonomous Okrug (3.51\%). The lowest absolute risk of tax systems is in Republic of Tyva (0.19\%) and Tomsk Oblast (0.46\%), where the tax return is below average. The relative risk of regional tax systems is greatest both in some high-return regions of Far East and Siberia, namely Sakhalin Oblast (0.461) and Zabaykalsky Krai (0.399), and in the backward Republic of Kalmykia (0.294). At the same time, Tyva Republic (0.021) and Tver Oblast (0.035) turned out to be the most stable at this level. Spatial differences in the relative risk of regional tax systems for regional budgets are clearly visible on the map of the Russian Federation presented in Fig. 4.

At the level of local budgets, the most risky are the tax systems of Chukotka Autonomous Okrug (1.9\%) and Magadan Oblast (1.39\%) located in the Far Eastern Federal District, while the least risky are the tax systems of Moscow and St. Petersburg (0.02\% each). Meanwhile, in Moscow the relative risk of the tax system is one of the highest (0.421), mainly because tax revenues from the capital city to the respective local budgets are minimal. By this indicator, the capital is second only to Chukotka Autonomous Okrug (0.557) and ahead of Magadan Oblast (0.406). The least risky for local budgets are the tax systems of some North Caucasus republics: North Ossetia-Alania (0.057) and Kabardino-Balkar Republic (0.068). At the local level, the standard deviation of the relative risk turned out to be 1.3 times higher than at the consolidated level, but it was only $5 \%$ of that at the federal level. Regional differences in the level of relative risk of tax systems for local budgets are presented on the map of the Russian Federation in Fig. 5.

Next, we decomposed the risk of regional tax systems by source and determined the contribution of each tax to the tax systems return and risk at each level of the budget system. In addition, we have divided the risk into internal and external components. Finally, the risk structures of the country and mid-regional tax portfolios were compared. The results are presented in Tabs. I-IV.

At the consolidated level (Tab. I), the largest contribution to the tax system revenue was made by four taxes and tax groups: Natural Resources Taxes (mainly Mineral Extraction Tax (MET)), Corporate Income Tax (CIT), Personal Income Tax (PIT) and Value Added Tax (VAT). In total, they provided 82.6\% of all tax receipts in the country. However, they were responsible for $113 \%$ of the country portfolio risk and $91.1 \%$ of the mid-regional portfolio risk.

The Corporate Income Tax contribution to the overall risk of the country's tax system was the largest and exceeded its contribution to the tax return by 3.8 times. However, in the mid-regional portfolio, this excess was noticeably lower, only 2 times. This can be explained by the dependence of the CIT in the regions on the same factors and, therefore, by the positive covariance of its return in the regions. This justifies leaving the CIT at the regional level. Meanwhile, the enormous contribution of CIT to the risks of both portfolios (country and mid-regional) is entirely due to its internal component (i.e. variance of its own tax return), while the covariance of its return with returns of other taxes is negative on average. This makes it expedient to combine CIT in the portfolio with other taxes, especially Personal Income Tax.

Natural resources taxes also made a significant contribution to the risk of the tax system at the consolidated level, albeit on average it was comparable to their contribution to tax return. The internal risk component of these taxes in the midregional portfolio is higher than in the country portfolio. Apparently, this is due to the negative correlation of Mineral Extraction Tax returns in various regions. This justifies its concentration at the federal level.

A similar situation is typical for another highly productive tax - Value Added Tax. In the country portfolio, regional fluctuations in its return neutralize each other, which allows it to be classified as a tax risk damper at the federal level. In regional tax portfolios, its contribution to risk is higher than its contribution to return, so here VAT plays the role of a risk enhancer. In addition, the positive covariance (procyclicality) of VAT with other taxes is significant, which enhances the risk of tax systems at both regional and country levels.

Among other taxes, Personal Income Tax proved to be a volatility damper at the consolidated level. Providing one fifth of tax revenue to the country's consolidated budget, PIT nevertheless reduces the risk of both country and mid-regional tax systems. This is largely due to the negative covariance of its return with return of other taxes and its negative correlation in different regions, which further reduces the risk of the country portfolio.

Now we can consider what happens to the structure of tax systems' return and risk after allocation of taxes to different levels of the budget system.

At the federal level (Tab. II), almost 83\% of federal budget revenues are generated by two groups of taxes: Natural Resources Taxes (actually MET) and VAT. The federal budget receives more than 97\% of taxes on natural resources, while VAT is fully assigned to this level. Corporate Income Tax (CIT) and Excise Taxes (ET) are two other taxes that are partially paid to the federal budget, but are less productive at this level. 


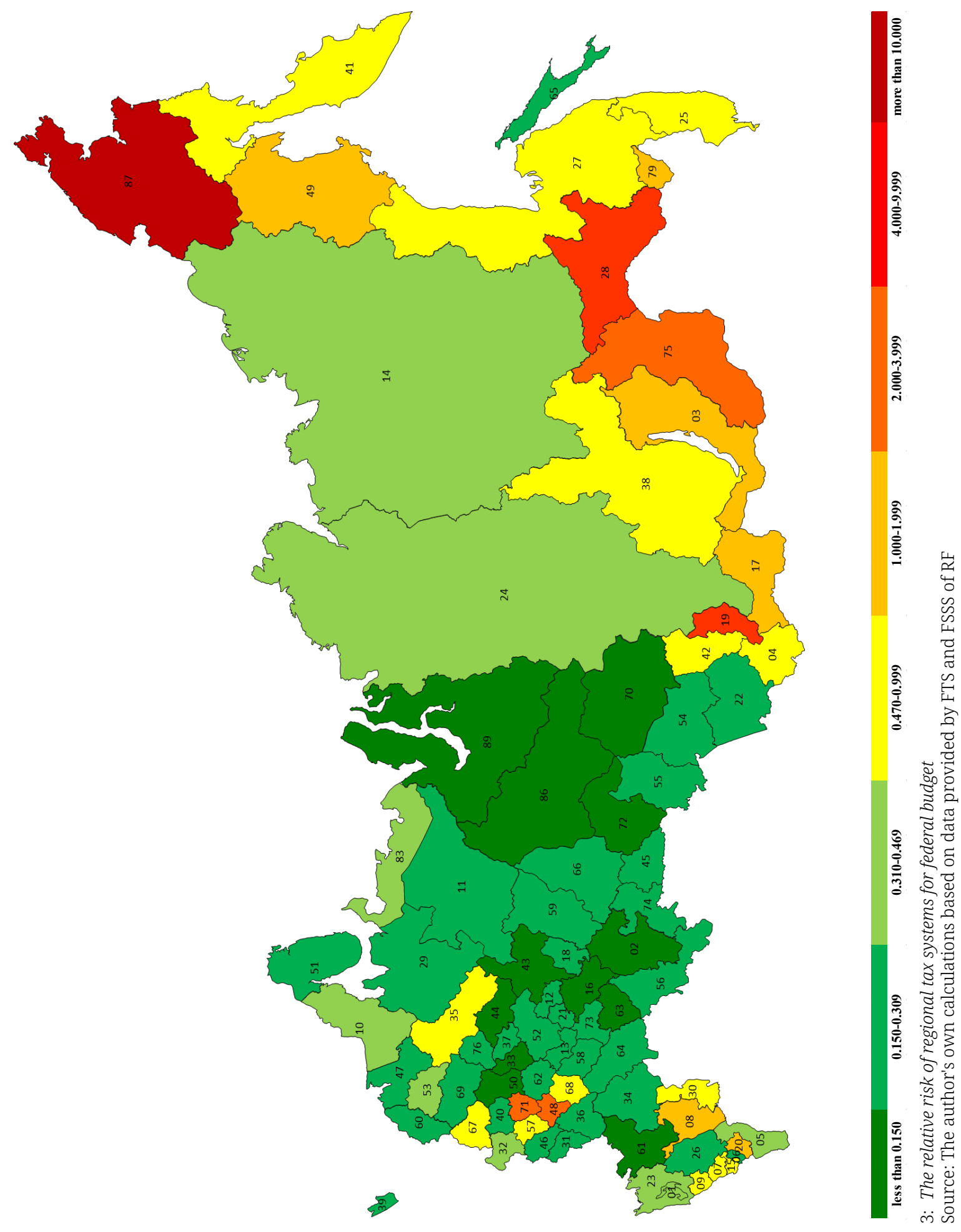




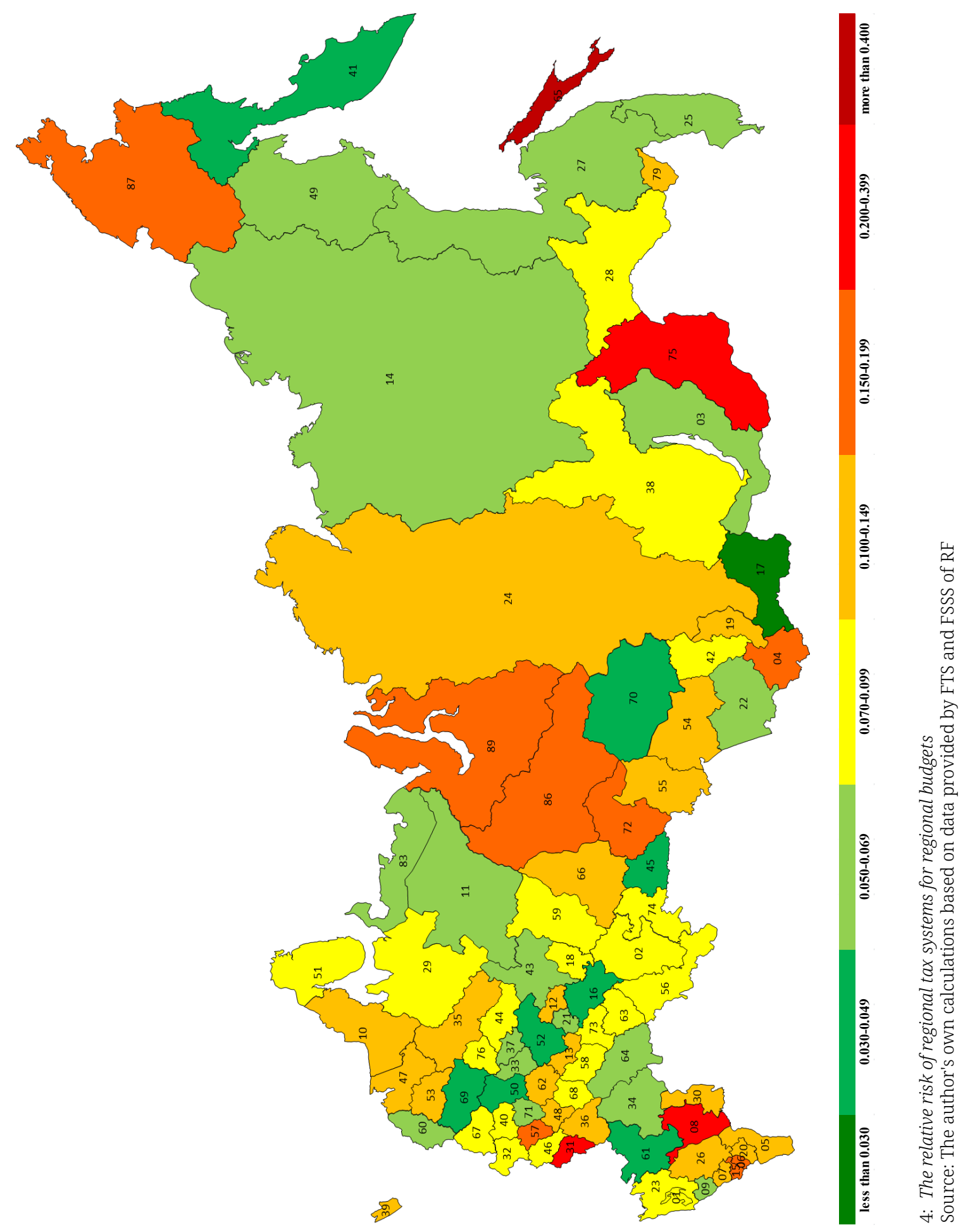




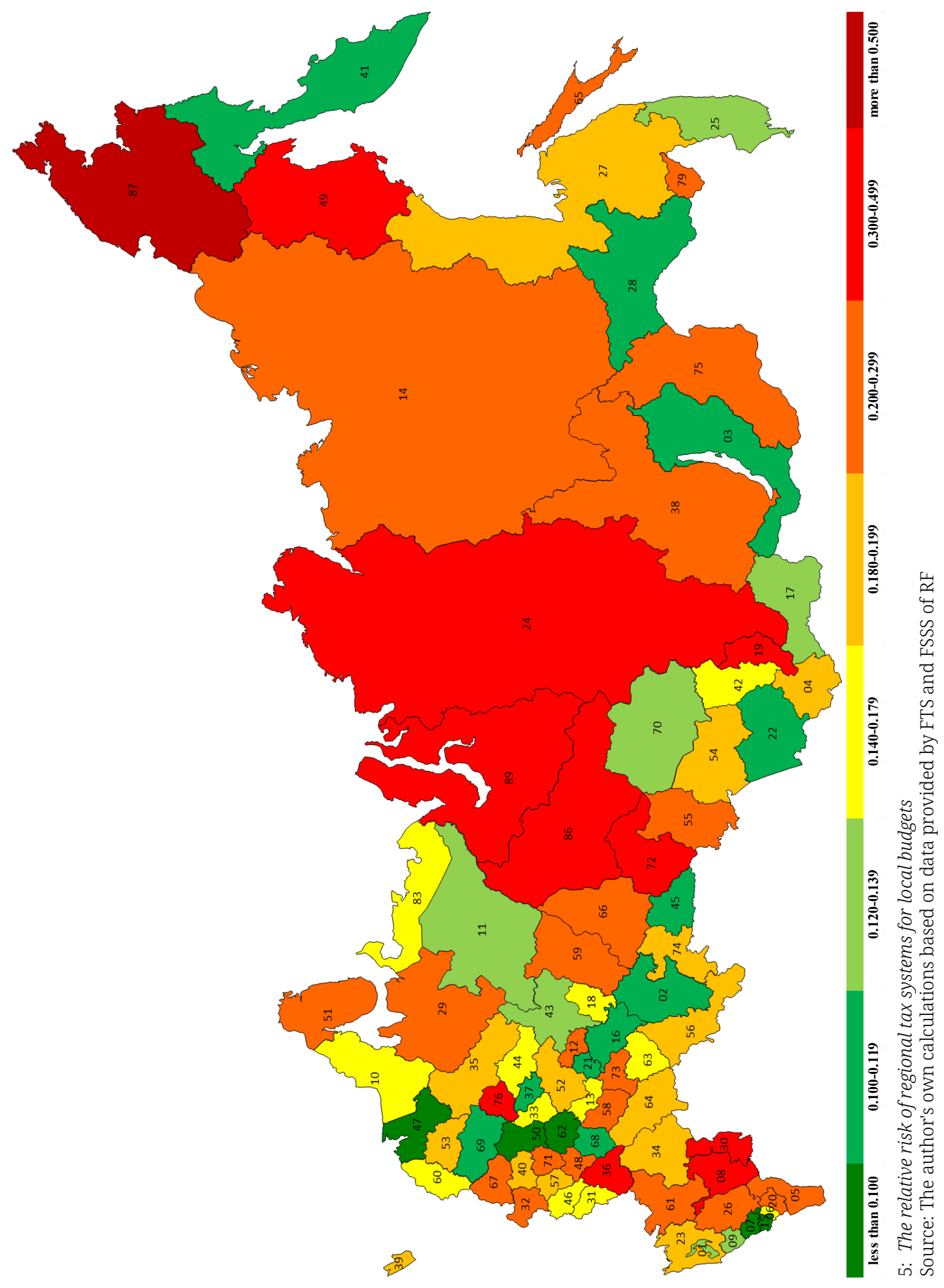


Despite the fact that the share of CIT in tax revenues of the country portfolio is almost 5 times less than the share of natural resources taxes, their contribution to the overall risk of the tax system is almost the same. At the federal level, the contribution of CIT to the risk of the tax system is more than 3.6 times greater than its contribution to return, while at the mid-regional level they are approximately equal. This confirms the role of CIT as an instability enhancer at federal level and justifies its retention in regional budgets. One of the reasons for this is that the CIT returns in different regions are positively correlated, which increases the risk of the country portfolio. Another reason is that the return of this tax is positively correlated with the return of other taxes in country portfolio, which is not the case of regional portfolios.

For Value Added Tax (VAT), the situation is exactly the opposite. Its attribution to the federal level reduces the risk of a country portfolio, which is associated with a negative correlation of the returns of this tax in different regions. At the same time, its positive relationship with other taxes strengthens the risks of both the country portfolio and the regional portfolios. Mineral Extraction Tax (MET), like VAT, contributes more to the return than to the risk of tax systems, but its role as a risk mitigation tool in the federal budget is more modest than that of VAT. The positive relationship of MET with other taxes significantly increases the risk of the country portfolio. Meanwhile, its negative correlation in different regions leads to a slight decrease in the contribution of MET to the total risk in the country's portfolio that substantiates its attribution to the federal budget.

At the regional level, the picture is slightly different (Tab. III), mainly due to the different structure of tax revenues. Almost 73\% of them are formed from PIT and CIT. While the first tax acts as a significant risk damper and provides relatively stable revenues to regional budgets, the second tax, on the contrary,

I: Decomposition of risks of tax systems of the Russian regions for the consolidated budget, \%

\begin{tabular}{|c|c|c|c|c|c|c|c|}
\hline \multirow{3}{*}{ Taxes } & \multirow{3}{*}{$\begin{array}{l}\text { Contribution } \\
\text { to return }\end{array}$} & \multicolumn{6}{|c|}{ Contribution to risk } \\
\hline & & \multicolumn{3}{|c|}{ Country portfolio } & \multicolumn{3}{|c|}{ Mid-regional portfolio } \\
\hline & & Total & Internal & External & Total & Internal & External \\
\hline Corporate Income Tax & 22.00 & 82.74 & 88.91 & -6.18 & 43.13 & 47.54 & -4.40 \\
\hline Personal Income Tax & 20.92 & -6.40 & 3.43 & -9.83 & -2.10 & 2.23 & -4.33 \\
\hline Value Added Tax & 17.58 & 14.90 & 8.87 & 6.02 & 24.12 & 16.38 & 7.74 \\
\hline Excise Taxes & 7.13 & -6.21 & 5.33 & -11.54 & 6.02 & 8.48 & -2.46 \\
\hline Property Taxes & 7.44 & -5.58 & 0.50 & -6.09 & -0.86 & 0.57 & -1.42 \\
\hline Natural Resources Taxes & 22.05 & 21.77 & 15.22 & 6.55 & 25.92 & 27.33 & -1.41 \\
\hline Duties & 0.22 & -0.46 & 0.00 & -0.46 & -0.12 & 0.00 & -0.12 \\
\hline Special Tax Modes & 2.66 & -0.75 & 0.18 & -0.93 & 3.89 & 3.04 & 0.85 \\
\hline Total & 100.00 & 100.00 & 122.45 & -22.45 & 100.00 & 105.57 & -5.57 \\
\hline
\end{tabular}

Source: The author's own calculations based on data provided by FTS and FSSS of RF

II: Decomposition of risks of tax systems of the Russian regions for the federal budget, \%

\begin{tabular}{|c|c|c|c|c|c|c|c|}
\hline \multirow{3}{*}{ Taxes } & \multirow{3}{*}{$\begin{array}{l}\text { Contribution } \\
\text { to return }\end{array}$} & \multicolumn{6}{|c|}{ Contribution to risk } \\
\hline & & \multicolumn{3}{|c|}{ Country portfolio } & \multicolumn{3}{|c|}{ Mid-regional portfolio } \\
\hline & & Total & Internal & External & Total & Internal & External \\
\hline Corporate Income Tax & 9.63 & 35.11 & 28.97 & 6.13 & 9.66 & 12.04 & -2.38 \\
\hline Personal Income Tax & 0.02 & 0.01 & 0.00 & 0.01 & 0.00 & 0.00 & 0.00 \\
\hline Value Added Tax & 37.31 & 19.74 & 13.55 & 6.19 & 33.61 & 25.06 & 8.55 \\
\hline Excise Taxes & 7.14 & 8.60 & 5.42 & 3.18 & 9.49 & 8.64 & 0.85 \\
\hline Property Taxes & 0.00 & 0.00 & 0.00 & 0.00 & 0.00 & 0.00 & 0.00 \\
\hline Natural Resources Taxes & 45.54 & 36.38 & 23.79 & 12.59 & 46.63 & 43.83 & 2.80 \\
\hline Duties & 0.23 & -0.21 & 0.00 & -0.21 & -0.07 & 0.00 & -0.07 \\
\hline Special Tax Modes & 0.13 & 0.39 & 0.02 & 0.36 & 0.68 & 0.63 & 0.05 \\
\hline Total & 100.00 & 100.00 & 71.76 & 28.24 & 100.00 & 90.20 & 9.80 \\
\hline
\end{tabular}

Source: The author's own calculations based on data provided by FTS and FSSS of RF 
plays a role of significant risk enhancer. Since the CIT rate of $20 \%$ is allocated $2 \%$ to the federal budget and $18 \%$ to regional budgets, the latter also bear the greatest risk of this tax. Meanwhile, a comparison of the risk structure of the country and mid-regional portfolios allows us to conclude that it is advisable to keep both taxes (CIT and PIT) at the regional level. Due to the positive covariance of regional returns for both taxes, their transfer to the federal budget leads to increased instability of the country's tax system. In addition, the average negative covariance of the return on PIT and CIT substantiates their integration into a single portfolio.

With regard to Excise Taxes, Property Taxes and revenue from Special Tax Regimes, the portfolio approach seems to indicate that their transfer to the federal level is effective from a risk management perspective. However, their assignment to the territorial (regional and local) levels is predetermined by the peculiarities of their accounting and control.
Finally, in Tab. IV we are presenting the results of the decomposition of the return and risk of tax systems at the local level. First of all, more than twothirds of tax revenues of local budgets are formed from the part of PIT transferred to them from regional budgets. While at the regional level this tax played the role of a significant damper of the volatility of total tax revenues, at the local level this property of PIT has noticeably weakened due to the poorer diversification of the local tax portfolios. In local budgets, its return positively correlates with returns of other taxes. Here, Property Taxes and Special Tax Modes are weak shock absorbers. Duties are the only taxes for which the correlation of return with return of other taxes is negative on average at the local level. However, their revenue is small, so they cannot significantly neutralize the total risk of the tax portfolio. Transferring some productive taxes (Property Taxes, Special Tax Modes) to a higher level of the budget system appears to be

III: Decomposition of risks of tax systems of the Russian regions for the regional budgets, \%

\begin{tabular}{|c|c|c|c|c|c|c|c|}
\hline \multirow[b]{2}{*}{ Taxes } & \multirow{2}{*}{$\begin{array}{l}\text { Contribution } \\
\text { to return }\end{array}$} & \multicolumn{6}{|c|}{ Contribution to risk } \\
\hline & & \multicolumn{3}{|c|}{ Country portfolio } & \multicolumn{3}{|c|}{ Mid-regional portfolio } \\
\hline Corporate Income Tax & 33.08 & 100.08 & 124.13 & -24.05 & 74.64 & 80.92 & -6.29 \\
\hline Personal Income Tax & 39.62 & 15.21 & 15.09 & 0.12 & 6.26 & 9.22 & -2.97 \\
\hline Excise Taxes & 7.14 & -10.02 & 2.20 & -12.22 & 7.37 & 8.97 & -1.60 \\
\hline Property Taxes & 14.09 & -8.47 & 2.21 & -10.68 & 0.91 & 2.35 & -1.43 \\
\hline Natural Resources Taxes & 1.14 & 10.17 & 1.62 & 8.55 & 3.78 & 2.61 & 1.17 \\
\hline
\end{tabular}

Source: The author's own calculations based on data provided by FTS and FSSS of RF

IV: Decomposition of risks of tax systems of the Russian regions for the local budgets, \%

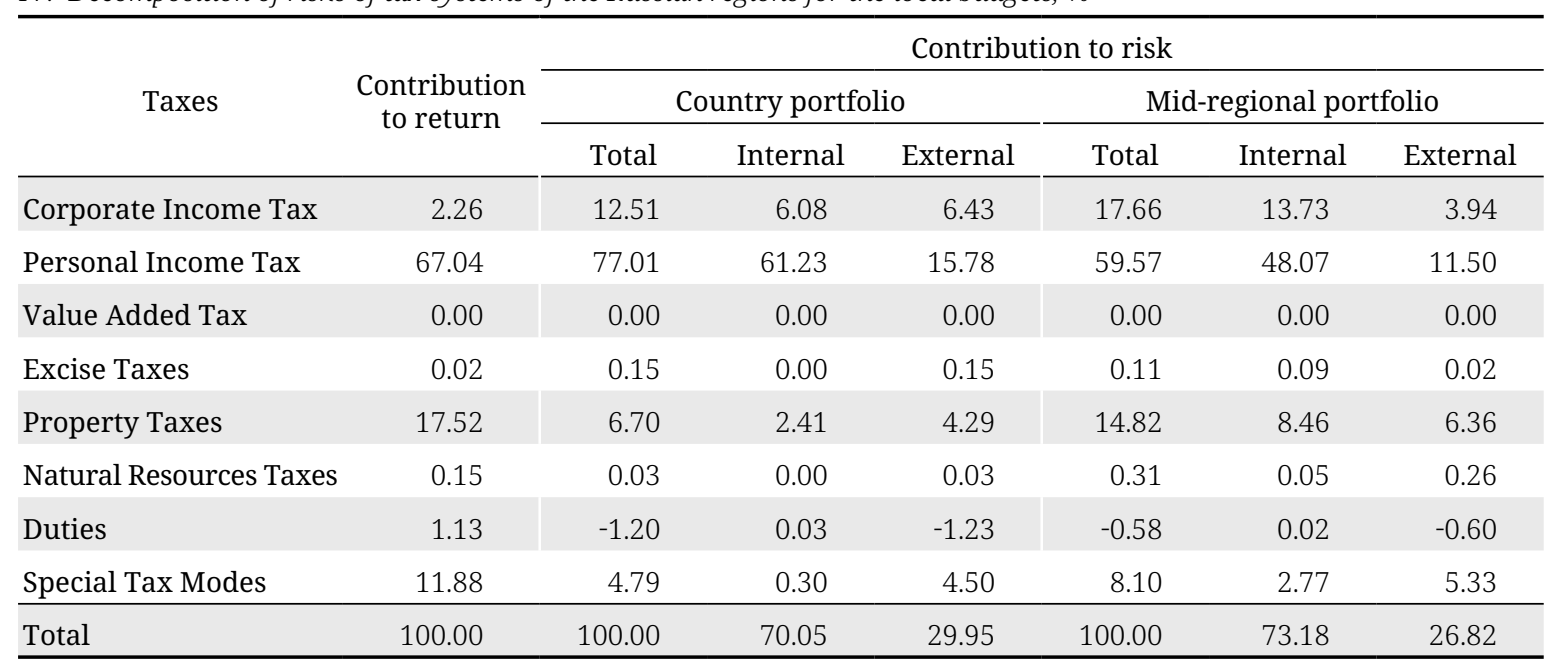

Source: The author's own calculations based on data provided by FTS and FSSS of RF 
effective in terms of risk management, but may not be appropriate for other reasons mentioned above. Meanwhile, the redistribution of CIT in favor of local budgets (with a decrease in the assigned share of PIT) can be effective, since this tax has an inverse correlation with some local taxes.

In conclusion of this part, we present the results of calculating the SSI, which is an indicator of the imbalance of tax system. At the level of consolidated budget, the SSI for the country portfolio is 0.693 , for the mid-regional portfolio - 0.333. This indicates a higher level of tax imbalance in the country than in the regions on average. At particular levels of the budget system, SSI indicators vary significantly. Tax revenues credited to regional budgets turn out to be the most unbalanced. At this level, the SSI is 0.781 for the country portfolio and 0.550 for the mid-regional portfolios. Tax revenue to local budgets is the most balanced (SSI is 0.194 and 0.178 for two types of portfolio, respectively). As for tax revenues to the federal budget, the degree of their imbalance at the country level is 0.323 , while at the regional average level it is only 0.046. The SSI indicator testifies in favor of the existing potential to reduce the risk of the tax system by managing its structure.

Based on this research, we can make some recommendations to tax and budget authorities. Since the returns of MET and VAT in the regions are inversely correlated, their assignment to the federal level allows to reduce the overall tax system risk, and in this the existing tax system of the Russian Federation is consistent with our findings. For the same reason, it makes sense to leave CIT entirely at the consolidated regional level. Moreover, it is effective to combine PIT and CIT in both regional and local budgets, because their returns are negatively correlated within the regions on average. We therefore recommend not only part of PIT but also part of CIT to be transferred to the local level, as this would create an effective diversification of local tax portfolios. Reimbursement of tax revenues at the federal level after crediting the CIT to regional budgets is advisable through the transfer of excise taxes or state duties, since their accumulation on a national scale reduces the overall risk for the federal budget.

More accurate recommendations can be obtained only by building an optimization model that takes into account a number of constraints and other objectives of budgetary policy, such as equalization of interregional imbalances in budgetary sufficiency and reduction of counter budget flows. This may be a task for future research.

\section{DISCUSSION}

The conducted study is devoted to a very important problem of risk management of regional tax systems at different levels of the budget system. Obviously, the mitigation of the risks of tax systems is associated with the effective diversification of the tax portfolio, which is achieved by proper distribution of taxes between the levels of the budget system. A certain progress in solving this problem is ensured by decomposing the risk and return of the tax portfolio by source (taxes and tax groups), identifying taxes that are relative risk enhancers and risk dampers, and assessing the overall imbalance of the tax system using the structural similarity index (SSI). These questions are posed and successfully solved in this paper.

We have obtained a number of new results that are consistent with our own earlier results, as well as those of other authors. In particular, the study by Deli et al. (2018) on OECD countries also proved that corporate income taxes made a major contribution to the risk of tax systems. The research on Ireland by Fitzgerald and Bedogni (2019) showed that the optimal portfolio should include primarily Personal Income Tax and Excise Taxes, which is also in line with our findings for Russia. These authors proposed linking the optimal portfolio with the creation of the Rainy Day Fund.

However, a number of aspects remain controversial. First of all, the question arises whether it is right to consider the variability of the tax return as a risk of the tax system. It should be noted that there are alternative approaches to assessment of the tax system risk, based on the calculation of the degree of fulfillment (non-fulfillment) of budgetary obligations, deviations of actual income indicators from the planned ones.

Secondly, even if we have adopted in this area a statistical understanding of risk as the tax return volatility, the methods of studying risk may vary considerably. On the one hand, through the transition from absolute to relative tax revenue, we were able to significantly strengthen the stationarity of time series. On the other hand, relative indicators can also have a pronounced trend, and in this case more sophisticated methods are required to separate volatility from the trend. To achieve this goal, Kriz (2016) used the time series decomposition method, based on the construction of ARIMA and GARCH models and application of the Hodrick-Prescott filter. However, the difficulty of using this method in the analysis of tax systems lies in the insufficient number of observations in the time series. In addition, it is still unclear whether the trend of relative indicator should be ignored in assessing the risk of tax systems. The positive slope of tax return trend should be treated in a different way than the negative one.

Thirdly, we assess the risks of tax systems within the system itself, without going beyond it. This does not allow to fully identify their origin. In this regard, our previous studies on the influence of sectoral structures of regional economies on the risks of regional tax systems (Malkina, 2017; Malkina and Balakin, 2017) partly shed light on this problem. However, in the future it is desirable to build econometric models linking the volatility of tax returns in the regions with the volatility of other macroeconomic indicators. 


\section{CONCLUSION}

In this study, we assessed the risk of tax systems in the Russian regions in 2006-2017 for different levels of the budget system (consolidated, federal, regional and local) using the portfolio approach. Based on the method of the variance decomposition, we determined the contribution of various sources (taxes and tax groups) to the overall risk of regional and country tax systems and distinguished between internal and external components within them.

Our research has shown that the highest absolute risk of tax revenues was characteristic of the federal budget, and the highest relative risk (as the ratio of absolute risk to tax return) was marked at the level of local budgets, followed by the federal budget with a small gap, while the consolidated regional budgets look the most stable. Interregional differences in relative tax risk turned out to be the largest at the federal budget level and the smallest at the regional budget level due to the centralization of the most unevenly distributed taxes, namely the Mineral Extraction Tax and Value Added Tax, at the federal budget level. We also revealed a weak and unstable positive relationship between the tax return and absolute tax risk in Russian regions, which manifested itself at all levels of the budget system.

Decomposition of the risk of tax systems by source led us to the following results. Corporate Income Tax was the main risk enhancer: its own volatility provided more than $100 \%$ of the country portfolio risk, when its external return covariances were negative, but much less influential. In contrast, Personal Income Tax was the main risk damper: the internal volatility of PIT was low, and the correlation of its return with returns of other taxes was negative. For natural resources taxes, we found a certain balance of their contributions to tax risk and return.

After the allocation of taxes to three separate levels of the budget system (federal, regional and local), the picture was somewhat different. The tax system risk at each level depends on the composition of portfolio and interaction of risks by individual taxes or by regions when they are combined into a single portfolio. At the federal budget level, CIT was the main amplifier of relative and absolute risk, while VAT and, to a lesser extent, MET turned out to be shock absorbers. At the regional level, the role of CIT as a risk enhancer was the greatest. Together with PIT, Property Taxes were the risk dampers at this level. Finally, at the local budget level, the role of PIT as a source of stability was much less than at other levels of the budget system.

Comparison of the risks of the country and mid-regional tax portfolios showed the feasibility of assigning MET and VAT to the federal budget level and leaving CIT and PIT at the regional level, as well as combining the last two into a single portfolio. Based on this, we can conclude that the current tax distribution system in the Russian Federation to some extent complies with these recommendations. Since the entire CIT is recommended to feed into the consolidated regional budgets, compensation for the lost revenues of the federal budget could be made at the expense of excise taxes and state duties. It is also advisable to transfer part of the CIT from the regional level to the local level, together with the PIT, which will ensure a better diversification of local tax portfolios.

To develop further recommendations on improving the existing structure of the distribution of taxes between the levels of the Russian budget system, it is necessary to take into account a number of taxation principles, tax collection features, and build an optimization model based on them. The author leaves the response to these challenges for the future.

Acknowledgements

The reported study was funded by RFBR according to the research project No. 19-010-00716, "Development of methodology and non-traditional methods for assessing financial instability".

\section{REFERENCES}

ALBRECHT, W. G. 2013. Managing Tax Revenue Volatility. Conference Proceedings of the International Academy of Business and Public Administration Disciplines, 27(1): 311-318.

CARROL, D. 2009. Diversifying Municipal Government Revenue Structures: Fiscal Illusion or Instability? Public Budgeting and Finance, 29(1): 27-48.

CORNIA, G. C. and NELSON, R. D. 2010. State Tax Revenue Growth and Volatility. Regional Economic Development. Journal of Federal Reserve Bank of St. Louis, 6(1): 23-58.

CORNIA, G. C., JOHNSON, R. B. and NELSON, R. D. 2016. Personal Income Tax Revenue Growth and Volatility. Public Finance Review, 454: 458-483.

DAUCHY, E. P. and BALDING, C. 2013. Federal Income Tax Revenue Volatility Since 1966. Working Papers of Center for Economic and Financial Research (CEFIR) No. w0198. CERIF. 
DELI, Y., RODRIGUEZ, A. G., KOSTARAKOS, I. and VARTHALITIS, P. 2018. Dynamic tax revenue buoyancy estimates for a panel of OECD countries. Papers WP592. Economic and Social Research Institute (ESRI).

FELIX, R. A. 2008. The Growth and Volatility of State Tax Revenue Sources in the Tenth District. Economic Review of Federal Reserve Bank of Kansas City, 3: 63-88.

FITZGERALD, K. and BEDOGNI, J. 2019. Examining the Volatility of Ireland's Tax Base in the Paradigm of Modern Portfolio Theory. The Economic and Social Review, 50(3): 429-458.

FRICKE, H. and SUSSMUTH, B. 2014. Growth and Volatility of Tax Revenues in Latin America. World Development, 54: 114-138.

GARRETT, T. A. 2009. Evaluating state tax revenue variability: a portfolio approach. Applied Economics Letters, 16(3): 243-246.

KRIZ, K. A. 2014. Improving Revenue Volatility Estimates Using Time-Series Decomposition Methods. In: $26^{\text {th }}$ ABFM Annual Conference. October 2-4, 2014, Grand Rapids, MI. Association for Budgeting and Financial Management.

LIAPIS, K., ROVOLIS, A. and GALANOS, C. 2014. The Tax Regimes of the EU Countries: Trends, Similarities and Differences. In: KARASAVVOGLOU, A. and POLYCHRONIDOU, P. (Eds.). Economic Crisis in Europe and the Balkans: Contributions to Economics. Heidelberg: Springer.

MALKINA, M. Y. 2016. Evaluation of the Factors of Russian Regions' Convergence / Divergence in the Level of Budget Provision Based on the Decomposition of the Theil - Bernoulli Index [in Russian: Ocenka faktorov konvergencii / divergencii rossijskih regionov po urovnyu byudzhetnoj obespechennosti na osnove dekompozicii indeksov Tejla - Bernulli]. Prostranstvennaya ekonomika [Spatial Economics], 3: 16-37.

MALKINA, M. Y. 2017. Influence of the industrial structure of economy on the risk level of Russian regions' tax systems. Acta Universitatis Agriculturae et Silviculturae Mendelianae Brunensis, 65(6): 2025-2035.

MALKINA, M. Y. and BALAKIN, R. V. 2015. Correlation Assessment of Tax System Risk and Profitability in the Russian Regions [in Russian: Ocenka vzaimosvyazi riska i dohodnosti nalogovoj sistemy v regionah Rossii]. Ekonomika regiona [Economy of Region], 3: 241-255.

MALKINA, M. Y. and BALAKIN, R. V. 2017. Tax system risk and yield assessments based on sectorial, regional and mixed-mode portfolios [in Russian: Ocenka riska i dohodnosti nalogovyh sistem na osnove otraslevogo, regional'nogo i smeshannogo portfelej]. Financy i credit [Finance and credit], 23(47): 2823-2842.

MARKOWITZ, H. 1952. Portfolio selection. The Journal of Finance, 7(1): 77-91.

MISHUSTIN, M. V. 2016. Factors of growth of tax revenues: a macroeconomic approach [in Russian: Faktory rosta nalogovykh dokhodov: makroekonomicheskiy podkhod]. Economic Policy [Ekonomicheskaya politika], 11(5): 8-27.

SALIN, V., PATRON, E. and STALLMANN, J. I. 2004. Rainy Day Funds for Municipalities Estimated with Value at Risk. In: North American Meetings of the Regional Science Association International. Seattle, WA.

SEEGERT, N. 2012. Optimal Taxation with Volatility. A Theoretical and Empirical Decomposition. University of Michigan, MI: Ann Arbor.

SEEGERT, N. 2017. Optimal tax portfolios: An estimation of Government Tax Revenue Minimum-Variance Frontiers. [Online]. Michigan University. Available at: http://www-personal.umich.edu/ seegert/ papers/OptimalTaxPortfolios_Seegert.pdf [Accessed: 2020, January 22].

SEYFRIED, W. and PANTUOSCO, L. 2003. Estimating the sensitivity of state tax revenue to cyclical and wealth effects. Journal of Economics and Finance, 27(1): 114-124.

SHARPE, W. F. 1970. Portfolio Theory and Capital Markets. New York, NY: McGraw-Hill.

SHORROCKS, A. 1982. Inequality Decomposition by Factor Components. Econometrica, 50(1): 193-211.

Contact information

Marina Malkina:mmuri@yandex.ru 